JED

24,1

2

Received 16 October 2020 Revised 4 January 2021 Accepted 8 February 2021

\section{Political institutions and economic performance in Ethiopia: an auto regressive distributed lag bound approach to co-integration}

\author{
Fikadu Abera Garedow \\ Department of Economics, Bonga University, Bonga, Ethiopia
}

\begin{abstract}
Purpose - The main objective of this study is to examine how political institutions affect economic performance in Ethiopia over the 1980-2019 time periods.

Design/methodology/approach - Mainly, the impact of political institution indicators including, level of democracy, political violence, democratic accountability and regime durability have been examined using auto regressive distributed lag (ARDL) bound test approach to co-integration and the error correction model.

Findings - This study confirms that level of democracy and democratic accountability has an adverse long effect on the economic performance of Ethiopia. On the other hand, political violence has a negative short-run causal effect on economic performance in Ethiopia. The study concluded that the deterioration of political institutions harmfully affected economic performance in Ethiopia.

Practical implications - Government policymakers should primarily pay attention to promoting and changing those political institutions that harm economic performance. Additionally, better management of political violence has important implications for fostering the economic performance of Ethiopia.

Originality/value - This study provides some valuable evidence on the nexuses between political institutions and economic performance in Ethiopia. Likely, this is the first investigation on the subject under the consideration to use time analysis and will vigorously contribute to the literature as well by employing the ADRL bound test. Previous studies have examined the impact of the institution on economic growth on a crosscountry basis. Further analysis is required to understand the effects of institutions such as level of democracy, political violence and democratic accountability on economic development.
\end{abstract}

Keywords ARDL model, Bound test, Political institution, Economic performance, Ethiopia

Paper type Research paper

\section{Introduction}

Living standards, as captured by average income per capita, vary dramatically across countries. Among many other factors, economic factors such as physical and human capital and technological advancement are identified as the proximate cause of the cross-country difference in economic development. However, the recent debate over the fundamental determinants of long term economic development emphasized the role of the institutional framework in explaining the cross-country differences in per capita output (Acemoglu and Robinson, 2008; Leeuwen, 2008; North, 1990a, b). "Institutions are the rules of the game in a society or, more formally, are the humanly devised constraints that shape human interaction and in consequence they structure incentives in human exchange, whether political, social, or economic" (North, 1990a, b). They are socially approved behavior models that restrict the

\section{JEL Classification - E02, O43, 055}

(C) Fikadu Abera Garedow. Published in Journal of Economics and Development. Published by Emerald Publishing Limited. This article is published under the Creative Commons Attribution (CC BY 4.0) licence. Anyone may reproduce, distribute, translate and create derivative works of this article (for both commercial and non-commercial purposes), subject to full attribution to the original publication and authors. The full terms of this licence may be seen at http://creativecommons.org/licences/by/4.0/ legalcode 
rationality of an individual and constrain or encourage specific behavior and assume that high-quality institutions encourage efficient use of limited production resources to fulfill the needs of society (Vitola and Senfelde, 2015a).

Over the last several decades, a massive amount of cross-country empirical research has examined the relationship between political institutions and development (Araee, 2016; Heshmati and Kim, 2017; Nawaz, 2015; Pereira and Teles, 2009). These studies concluded that political institution has a positive impact on economic growth. The other studies found a negative relationship between democratic institutions and economic development (Abeyasinghe, 2004; Aisen and José, 2013; Iqbal and Daly, 2014; Kurzman et al., 2002; Tavares and Wacziarg, 2001). Additionally, an increasing number of study established the weaker and ineffective role of the institution on economic performance in Africa (Asfaw and Mbeche, 2006; Effiong, 2015; Rachdi and Saidi, 2015; Fikadu et al., 2019), particularly SubSaharan African (SSA). Region institutional environments are affected by poor enforcement of the rule of law, corruption, mismanagement, absence of strong civil society and political interference.

Most of the above evidence established that institutions matter for economic growth and development, although the conclusion made is inconsistent. The question of interest in this study is that "does political institution matter for economic performance in Ethiopia?". There is no framework for political power in Ethiopia and no democratic transparency (Araya, 2019; Bayu, 2019). The political climate is shrinking, marked by a lack of democratic culture, the destruction of the rule of law, the economic monopolization of the party and petty corruption. Although Ethiopia's economy is rapidly growing than other SSA, extreme poverty and highincome inequality that still exist has root in its failure of political institutions (Asefa, 2018). However, such a cross-sectional study did not tell us to what extent political institutions influence economic growth over time. Thus, further research is required to understand how the level of democracy, political violence and democratic accountability influence economic performance.

To this extent, the current study aimed to examine by what means political institutions affect economic performance in Ethiopia using autoregressive distributed lag (ARDL) and error correction (EC) time series models. The empirical investigation uses the time series data of Ethiopia over the period of 1980-2019. There is a vigorous empirical study regarding the between institutions and economic performance.

\section{Literature review}

\subsection{Theoretical literature}

There is a wide discussion about the causes of economic performance disparities across the globe. The neoclassical economist stressed investment and saving long years ago as the key determinant of the economic growth of a country. The new growth theory later highlighted a country's human resources and innovation potential as a vital determinant of economic growth. The new growth theory, unlike the neoclassical theoretical view, assumes technological advancement and technology as an endogenous factor in the development of economic activity. The other theoretical strands, revived by the new institutional economy, have recently emphasized the crucial role of institutions in economic performance (Aron, 2000; North, 1990a, b; Popescu, 2012; Sardadvar, 2011). In fact, according to North (1990a, b), "institutions are the rules of the game in a society or, more formally, are the humanly devised constraints that shape human interaction and in consequence they structure incentives in human exchange, whether political, social or economic."

The new theory integrates the theory of institutions into mainstream economics and contributes to explaining economic development by considering not only standard factors of production but also institutions (Aron, 2000; Acemoglu et al., 2005; North and Thomas, 1973; Temin, 2008; Vitola and Senfelde, 2015b). Henceforth, development practitioners and 
JED

24,1

4

policymakers have recognized that institutions affect economic growth by fostering better policy choices by creating an incentive structure that helps to reduce transaction costs, minimize uncertainty and promote efficiency, maintain social harmony. However, weak institutions can increase volatility, unpredictability, instability, corruption and the cost of transactions (Acemoglu and Robinson, 2010a, b; Vitola and Senfelde, 2012) .

\subsection{Empirical literature}

Following the recent advancement in econometrics methodology, an enormous amount of empirical work examining the relationship between institutions and growth has exponentially increased in recent decades. However, there is no consensus among the literature on how political institutions affect affects economic growth (Knutsen, 2012). According to Tavares and Wacziarg (2001), democracy hinders growth by reducing the rate of physical capital accumulation and, less robustly, by raising the ratio of government consumption to gross domestic product (GDP). The study indicates that democratic institutions are responsive to the demands of the poor by expanding access to education and lowering income inequality but do so at the expense of physical capital accumulation. Kurzman et al. (2002) affirm that democracy is an obstacle for promoting investment-the single strongest predictor of economic growth-because democracies regimes dare not impose unpopular measures to increase investment but only an authoritarian regime will be able to do so. Rachdi and Saidi (2015) state that existing literature provides conflicting views on the effect of democracy on economic growth. Using a generalized method of moments (GMM) system, the study shows that democracy, measured by Institutionalized Democracy Score, Institutionalized Autocracy Score, Competitiveness of Executive Recruitment, Openness of Executive Recruitment and Executive Constraints have a robust and negative impact on growth in Middle East and North Africa (MENA) countries.

Aisen and José (2013), using the system-GMM estimator, found that political instability adversely affects development by decreasing productivity growth rates and to a lesser degree, physical and human capital accumulation. Furthermore, the study demonstrates that economic freedom and ethnic homogeneity are beneficial to development, whereas democracy may have a slight negative effect. Iqbal and Daly (2014) concludes that institutional qualities promotes economic growth in strongly democratic economies and fail to boost growth in democratically weak countries. Das and Quirk (2016) concludes marketcreating and market-stabilizing institutions have been found to be effective in fostering economic growth. It also found that institutions such as "democracy" that legitimize the economy are not inherently ideal for growth in developing countries.

Araee (2016), using the Generalized Method of Moments (GMM) found that democracy has a positive and robust effect on economic growth, and it is influenced by political instability more than democracy. Nawaz (2015) examines the impact of various institutions on economic growth using panel data for 56 countries over the period 1981-2010, at an aggregated level for world representative sample as well as for the sample disaggregated by the development level. Using the fixed-effects model and system GMM, the empirical analysis confirms a positive relationship between institutions and economic growth, but greater impact highincome countries as compared to low-income countries. Heshmati and Kim (2017) examined the effect of democracy on the economic growth of a panel data of 144 countries. The finding shows that democracy had a robust positive impact on economic growth.

Asfaw and Mbeche (2006) examines the role of institutions in the development process of African countries. Accordingly, institutions have played a greater role in the economic development of several East Asian countries, but in Africa they are weaker and ineffective because of poor enforcement of the rule of law, corruption, mismanagement, absence of strong civil society and political interference. Using panel regressions, Bodea and Elbadawi (2008) found that organized political violence, especially civil war, significantly lowers long- 
term economic growth. According to this study, SSA has been disproportionately impacted by civil war, widening its income gap relative to East Asia. Matthew and Adegboye (2014) investigated the impact of trade openness and institutions on economic growth in 30 SSA countries using least square dummy variables and the GMM. The study revealed that institutions had a significant positive impact on economic growth but trade openness only had a little significance on growth in the region. Using static panel regression, Masaki and Walle (2014) found that level democracy is positively associated with economic growth in SSA countries that have remained democratic for longer periods of time. Using robust estimation of system GMM, Fikadu et al. (2019) found that Eastern African economies could not explained by political institution, considering level of democracy (Polity2) as proxy.

Limited studies assessed the role of institutions in the development process of Ethiopia. Araya (2019) explored what strategic controls and accountability measures are in place to regulate the rule-making process. The results revealed that in Ethiopia there is no political control mechanism in place, and no accountability measures have been taken. Bayu (2019) critically analyzes good governance performance using World Bank Governance Indicator Framework. The study revealed that the shrinking political landscape has made citizens develop a kind of attitude that their vote has no power to bring any difference and the political culture "democratic centralism" has made elected government to be accountable for the party channels, instead of ensuring accountability for their constituencies. In addition, huge interference of politics in the civil service, the highly politicized nature of the public institution, the prevalence of corruption and weak political commitment, and weak and vulnerable governance institutions challenged government effectiveness. Moreover, the study states lack of democratic culture, the erosion of the rule of law, party monopolization of the economy, as well as the politicization of the civil service, the incidence of grand and petty corruption is on the rise and it continues to be perceived as a pervasive problem.

\subsection{Institutional development and economic performance in Ethiopia}

The institutional development experience of Ethiopia has been described into three historically distinct periods: (1) the period 1941-1974 was described as period of institution building, (2) 1974-1991 the period of human and economic distress and (3) from 1991 to the 2018 the period of restructuring and experimentation with ethnic federalism. Many institutions that are still important to our lives today, although battered and tattered, trace their roots to this time, were characterized by some solid achievements in the pre-1974 periods. Such institutions cover the full spectrum of public policy, economics, education and infrastructure (Asefa, 2018). In 1974, the provisional soldiers' administrative council known as the Derg regime overthrew Haile Selassie I. Then the Derg set up a military style socialist government. However, droughts, famine and insurrections rushed through the fall of the Derg. The Tigrayan People's Liberation Front (TPLF) merged with other ethnically oriented resistance movements in 1989 to form the Revolutionary Democratic Front of the Ethiopian Peoples (EPRDF).

Although a multiparty structure was introduced by the EPRDF government in 1991, one party dominated the political landscape and it was marked by authoritarianism and repression. This was compounded by the implementation of a series of draconian laws by the government that permitted the state to censor political activists and journalists, decimate political opposition and limit freedom of speech and association. Institutions such as the National Electoral Board of Ethiopia, the Commission on Human Rights and the judicial system that is meant to be accountable to parliament have been ineffective and extremely partisan among the public. The government's unwarranted impact on the function of such institutions has eroded the legitimacy of the institutions and made them fragile and incapable of ensuring control and balance in the nation. This has resulted in a significant lack of unbiased outlets to rectify public concerns and inevitably lead to prolonged violent demonstrations, the only means of communication with the government (IPSS, 2020). 
JED

24,1

6

Over the past decades, Ethiopia's economic growth has been relatively fast and stable. In 2004-2014, real GDP growth averaged $10.9 \%$. By taking population growth of $2.4 \%$ per year into account, actual per capita GDP growth averaged $8.0 \%$ per year. This rate of growth is the highest ever witnessed by the country and also exceeds what was achieved in that time by low-income and SSA countries. With a change to an even higher gear in 2004, rapid economic growth began in 1992. As average production increased from $0.5 \%$ in $1981-92$ to $4.5 \%$ in 1993-2004 and to $10.9 \%$ in 2004-14, econometric research confirms a history of two growth accelerations. Shortly after the political and economic change of 1991, the first 'gear shift took place with the collapse of the communist Derg dictatorship and the implementation of a more market-oriented economy. In turn, the subsequent government of the EPRDF initiated a series of systemic economic reforms during the 1990s, paving the way for the second acceleration of growth beginning in 2004. Interestingly, structural economic reforms have been largely absent from the recent success story of Ethiopia, although if introduced, they offer promising growth prospects (WB, 2016).

The insight from international and regional research reviewed above found mixed results on the impact of political institutions on economic growth. The explanation for the best of this research may be attributed to robust econometrics studies of the sample heterogeneity, even though previous studies used sophisticated econometrics methods. Whereas, the research on political institutions and economic growth nexuses carried out in Ethiopia was based on a cross-sectional design. To the best of this study, the ARDL provides better insight to understand the dynamism's impact of the political institution on economic performance. To this extent, this study aims to investigate how political institutions affect economic performance in Ethiopia using employing an ARDL time series.

\section{Research methodology}

\subsection{Data}

This study has used annual time series data of Ethiopia over the 1980-2019 time period. The data were sourced from different databases including the United Nations Conference on Trade and Development (UNCTAD) data center, World Bank Development Indicator (WDI), and the International Monetary Fund (IMF), Center for Systematic peace (CSP) and International County Risk Guide (ICRG). Table 1 show the brief descriptions, the source and expected sign of variables included in the analysis. As the purpose of this study is to examine the impact of political institutions on economic performance, real GDP per capita, in US dollars at constant prices (2015), is used as a proxy measure of economic performance. The indicator is a basic economic indicator and measures the level of total economic output relative to the population of a country. The Center for Systematic peace (CSP) is measuring the political regime characteristics and political violence of many states in the world recorded in its Polity V databases. Among such numerous indicators, POLITY2, Political violence (MPV) and regime durability (DBY) were included in this study.

The first and most important indicator of political institution is the level of democracy which is measured by POLITY2. Monty G. Higher level of democracy would have positive impact on economy. Political violence is the deliberate use of power and forces to achieve political goals and characterized by both physical and psychological acts aimed at injuring or intimidating populations. Political violence diminishes individuals' trust in the moral organization of society, government entities; lessen the willingness of individuals to engage in political activities and processes of democracy (Marshall, 2019). Regime durability is the number of years since the most recent regime change or the end of the transition period defined by the lack of stable political institutions. It is calculated as the first year during which a new polity is established is coded as the baseline "year zero" (value $=0$ ) and each subsequent year adds one to its value consecutively until a new regime change or transition period (Marshall and Gurr, 2020). 


\begin{tabular}{|c|c|c|c|c|}
\hline Variable & Brief description & $\begin{array}{l}\text { Expected } \\
\text { sign }\end{array}$ & Source & $\begin{array}{l}\text { Auto } \\
\text { regressive }\end{array}$ \\
\hline$G D P C$ & Real GDP per capita measured in 2015 US\$ & NA & UNDP & \\
\hline FDI & Foreign direct investment per capita & + & UNDP & \\
\hline TOPEN & Trade openness which measured in US\$ & + & UNDP & \\
\hline POPG & Percent of annual population growth & + & WB & \\
\hline INF & Inflation as percent of consumer price index & - & IMF & \\
\hline POLITY2 & $\begin{array}{l}\text { Level of democracy measured from }-10 \text { (strong autocracy) to }+10 \\
\text { (strong democracy) }\end{array}$ & + & CSP & \\
\hline MPV & Political violence measured from 0 (no violence) to 10 (high violence) & - & CSP & \\
\hline DEA & $\begin{array}{l}\text { Democratic accountability which measured from } 0 \text { (less accountable) to } \\
6 \text { (more accountable government) }\end{array}$ & + & ICRG & \\
\hline $\mathrm{DM}_{1991}$ & $\begin{array}{l}\text { Time Dummy having value of " } 1 \text { " if the time period is } 1991 \text {, " } 0 \text { " } \\
\text { otherwise }\end{array}$ & - & CSP & \\
\hline DBY & The number of years since the most recent regime change & $+/-$ & CSP & \\
\hline \multicolumn{4}{|c|}{$\begin{array}{l}\text { Note(s): the mathematical operations “+”, “-” and “+/-" indicate that the variables will be expected have } \\
\text { positive impact, negative impact and } \pm \text { negative or positive impact on economic performance respectively, and } \\
\text { NA = not applicable } \\
\text { Source(s): Author own compilation }\end{array}$} & $\begin{array}{r}\text { Table 1. } \\
\text { Variable descriptions } \\
\text { and expected sign and } \\
\text { source of the data }\end{array}$ \\
\hline
\end{tabular}

The Last political institution variable that was selected to be included in the analysis is democratic accountability. This is a measure of how responsive government is to its people, on the basis that the less responsive it is, the more likely it is that the government will fall, peacefully in a democratic society but possibly violently in a nondemocratic one (Howell, n.d.). The study also included some macroeconomic variables that are important determinants of economic growth. Accordingly, FDI per capita (FDI), trade openness (TOPEN), annual population growth (POPG) and inflation (INF) were introduced to the baseline model.

Table 2 shows the summary statistics for the variables included in the study. The average value of GPD per capita (GDPC) is $\$ 367.199$, while minimum and maximum values are $\$ 208.111$ and 768.225 , respectively. In addition, the result shows that the political-institutional environment in Ethiopia is not good. On average, the level of democracy (POLITY2) is negative 2.846, while minimum and maximum values are -8 and 1 , which has a standard deviation of 3.468. Likewise, political violence (MPV) and democratic accountability (DEA) has an average score of 2.625 and 2.906, respectively. The average number in which regime can change is around 6 years, while the maximum number year 15. On average FDI and TOPEN perform $6.398 \$$ / per capita and $\$ 2408.414$, respectively. The standard deviation of FDI and TOPEN is 10.585 and 2467.688, which almost near average. POG and INF has mean

\begin{tabular}{lrccc}
\hline Variable & Mean & Standard deviation & Minimum & Maximum \\
\hline GDPC(in \$) & 367.199 & 152.802 & 208.1115 & 768.2254 \\
POLITY2 & -2.846 & 3.468 & -8 & 1 \\
MPV & 2.625 & 2.657 & 0 & 6 \\
DEA & 2.906 & 1.094 & 1 & 4.5 \\
DBY & 5.974 & 4.451 & 0 & 15 \\
FDI & 6.398 & 10.585 & -0.065 & 39.988 \\
TOPEN & 2408.414 & 2467.688 & 435.894 & 8590.200 \\
INF & 9.275 & 10.250 & -9.146 & 44.371 \\
POPG & 2.946 & 0.343 & 1.878 & 3.591
\end{tabular}

Source(s): Author computation using data from UNCATD, WB, CSP, IMF and ICRG

Table 2. Summary statistics 
JED

24,1

8

of 9.275 and 2.946 , respectively, while standard deviations are 10.250 and 0.343 . The standard deviation of POPG is far lower than average value.

\subsection{Econometric model specification}

The method selection for time series analysis is based on the unit root test results which determine the stationarity of the variable. If all the variables of interest are stationary, the methodology becomes ordinary least square (OLS) or vector autoregressive (VAR) models can provide unbiased estimates. But, if all the variables of interest are nonstationary, OLS or VAR models may not be appropriate because the nonstationary variables can be made stationary by taking first difference which might lose important information of the variables. Similar problem arises when the series are of integrating of order of mixed type. However, ARDL model which is an OLS based model is appropriate for both nonstationary time series as well as for times series with mixed order of integration (Shrestha and Bhatta, 2018).

Therefore, following Mankiw et al. (1992) growth model augmented with political institution variables, we specify the following functional forms:

$$
\mathrm{GDPC}_{t}=f\left(\text { Poliy }_{t} \mathrm{MPV}_{t}, \mathrm{DEA}_{t}, \mathrm{FDI}_{t}, \mathrm{POPG}_{t}, \mathrm{TOPEN}_{t}, \mathrm{INF}_{t}, \mathrm{DBY}_{t}, \mathrm{DM}_{1991}\right)
$$

Where: " $"$ " is the time ranging from 1980 to 2019 G.C. The abbreviation GDPC stands for real GDP per capita and it the dependent variable of this study. The variable $\mathrm{DM}_{1991}$ is the time dummy which is used to capture unexpected shocks where complete state failure happened to the country, in this case, Ethiopia. The other variables are as noticed and defined in the data description section.

Thus, generally, we specify an ARDL $(p, q)$ model that examines the effect of political institution on economic performance in Ethiopia as in the following equation;

$$
\begin{aligned}
\ln \mathrm{GDPC}_{t}= & \beta_{0 i}+\sum_{i=1}^{p} \alpha_{i} \ln \mathrm{GDPC}_{t-i}+\sum_{i=0}^{q} \beta_{1 i} \mathrm{Polity}_{t-i}+\sum_{i=0}^{q} \beta_{2 i} \mathrm{MPV}_{t-i}+\sum_{i=0}^{q} \beta_{3 i} \mathrm{FDI}_{t-i} \\
& +\sum_{i=0}^{q} \beta_{4 i} \mathrm{POPG}_{t-i}+\sum_{i=0}^{q} \beta_{5 i} \mathrm{LNTOPEN}_{t-i}+\sum_{i=0}^{q} \beta_{65 i} \mathrm{DEA}_{t-i}+\sum_{i=0}^{q} \beta_{7 i} \mathrm{INF}_{t-i} \\
& +\sum_{i=1}^{p} \beta_{8 i} \mathrm{DBY}_{t-i} \sum_{i=1}^{p} \beta_{9 i} \mathrm{DM}_{1991}+\epsilon_{t}
\end{aligned}
$$

Where: $p$ and $q$ are the length of the lag for dependent and independent variables respectively, $\alpha$ is the coefficient of lag period of real GDP per capita, $\beta_{0}$ is the intercept, $\beta_{1}, \beta_{2}, \ldots, \beta_{9}$ are the coefficients of regressors, $\epsilon_{t}$ is an error term. It is important to note that the GDPC and TOPEN are used in regression in natural logarithmic form. The institutional variables are measured in ordinal values and the other macroeconomic variables are reported in percentage values, hence inappropriate to take a natural logarithm to transform.

\subsection{Estimation techniques}

To estimate Eqn (2), the first step is to carry out unit root test in the time series variables. The study used Augmented Dickey-Fuller (ADF) test in testing the unit root in the series, with and without a trend. The ADF model test unit root as follows;

$$
\Delta y_{t}=\mu+\delta y_{t-1}+\sum_{i=1}^{k} \beta_{i} \Delta y_{t-1}+e_{t}
$$


Where, $\delta=\alpha-1, \alpha, \alpha$ is the coefficient of $y_{t-1}$, and $\Delta y_{t}$ is first difference of $y_{t}$. The null hypothesis of $\mathrm{ADF}$ is $\delta=0$ against the alternative hypothesis of $\delta<1$. If we do not reject null, the series is nonstationary whereas rejection means the series is stationary. After performing stationary test, the next is to conduct a co-integration test to establish a long-run relationship. In this study, bound test approach proposed by Pesaran et al. (2001) to co-integration test is employed. The ARDL bound test equation can be specified as in the following;

$$
\begin{aligned}
\Delta \ln \mathrm{GDP}_{p} c_{t}= & \beta_{0 i}+\sum_{i=1}^{p} \alpha_{i} \Delta \ln \mathrm{GDP} p c_{t-i}+\sum_{i=0}^{q} \beta_{1 i} \Delta \mathrm{Polity}_{t-i}+\sum_{i=0}^{q} \beta_{2 i} \Delta \mathrm{MPV}_{t-i} \\
& +\sum_{i=0}^{q} \beta_{3 i} \Delta \mathrm{FDI}_{t-i}+\sum_{i=0}^{q} \beta_{4 i} \Delta \mathrm{POPG}_{t-i}+\sum_{i=0}^{q} \beta_{5 i} \Delta \mathrm{LNTOPEN}_{t-i} \\
& +\sum_{i=0}^{q} \beta_{6 i} \Delta \mathrm{DEA}_{t-i}+\sum_{i=0}^{q} \beta_{7 i} \Delta \mathrm{INF}_{t-i}+\sum_{i=0}^{q} \beta_{8 i} \Delta \mathrm{DBY}_{t-i}+\sum_{i=0}^{q} \beta_{9 i} \Delta \mathrm{DM}_{1991} \\
& +\lambda_{1} \operatorname{lnGDP}_{t-i}+\lambda_{2} \mathrm{Polity}_{t-i}+\lambda_{3} \mathrm{MPV}_{t-i}+\lambda_{4} \mathrm{FDI}_{t-i}+\lambda_{5} \mathrm{POPG}_{t-i} \\
& +\lambda_{6} \mathrm{LNTOPEN}_{t-i}+\lambda_{7} \mathrm{DEA}_{t-i}+\lambda_{8} \mathrm{INF}_{t-i}+\lambda_{9} \mathrm{DBY}_{t-i}+\lambda_{10} \mathrm{DM}_{1991}+u_{t}
\end{aligned}
$$

Where the vector $\beta^{\prime}$ is the short-run coefficients, $\lambda^{\prime}$ is the long-run coefficients and $u$ is the error component. F-test is applied for the joint null hypothesis that the coefficients on the level variables are jointly equal to zero. If the test statistic falls below the lower critical value, denoted as I (0), we cannot reject the null hypothesis of no co-integration. But, if the test statistic falls above the upper critical value, denoted as I (1), we can reject the null hypothesis of no cointegration (Pesaran et al., 2001). After confirming the existence long-run equilibrium relationship, the ARDL model of the co-integrating vector is reparameterized into a dynamic error correction model (ECM) by linear transformation. The ECM integrates the short-run dynamics with the long-run equilibrium without losing long-run information and avoids problems. In that case, we specify ECM version of ARDL as in the following;

$$
\begin{aligned}
\Delta \ln \mathrm{GDPC}_{t}= & \beta_{0 i}+\sum_{i=1}^{p} \beta_{1 i} \Delta \ln \mathrm{GDPC}_{t-i}+\sum_{i=0}^{q} \beta_{2 i} \Delta \mathrm{Polity}_{t-i}+\sum_{i=0}^{q} \beta_{3 i} \Delta \mathrm{MPV}_{t-i} \\
& +\sum_{i=0}^{q} \beta_{4 i} \Delta \mathrm{FDI}_{t-i}+\sum_{i=0}^{q} \beta_{5 i} \Delta \mathrm{POPG}_{t-i}+\sum_{i=0}^{q} \beta_{6 i} \Delta \mathrm{LNTOPEN}_{t-i} \\
& +\sum_{i=0}^{q} \beta_{7 i} \Delta \mathrm{DEA}_{t-i}+\sum_{i=0}^{q} \beta_{8 i} \Delta \mathrm{INF}_{t-i}+\sum_{i=0}^{q} \beta_{9 i} \Delta \mathrm{DBY}_{t-i}+\sum_{i=0}^{q} \beta_{10 i} \Delta \mathrm{DM}_{1991} \\
& +\lambda \mathrm{ECT}_{t-1}+\omega_{t}
\end{aligned}
$$

Where, $\lambda$ represents of error correction term (ECT) and $\omega_{t}$ is the error component associated with ECM.

\subsection{ARDL diagnostic tests}

The robust and unbiased estimation depends on the goodness of fit, which can be evaluated by $R 2$. When the value $R 2$ is closer to 1 , the model is considered to be better. In addition, Durbin Watson (DW) statistics have used to test whether there is autocorrelation in residuals. 
JED

10

Table 3.

$\mathrm{ADF}$ unit root test results
If the value of DW is close to two, then the model is considered to be "utocorrelation free". The Jarque-Bera normality test is used to determine whether the regression errors are normally distributed, which is a joint asymptotic test whose statistic is calculated from the skewness and kurtosis of the residuals. The test for the presence of heteroscedasticity problems is conducted by the Breusch-Pagan-Godfrey test. It tests the null hypothesis that the residuals are both homoskedastic. The larger value of the probability value is desired to retain the null hypothesis of homoscedasticity. The stability of the model, whether the parameters of the estimated model are stable across various subsamples of the data, is examined by cumulative sum (CUSUM) and cumulative sum (CUSUM) square tests.

\section{Result and discussion}

Table 3 shows the result of the unit root test for separate variables included in this study. The study evaluated if variables stationary at level, and after the first difference, by specifying a model with intercept only, with intercept and trend. As the result, all variables are confirmed to have a unit root at level, except for inflation. Inflation is stationary at the level at $1 \%$ level of significance. After the first differences, all of the variables are stationary at $1 \%$ and $5 \%$ level of significance. The result indicates that the variables in this study are a mixture of integrated order of $\mathrm{I}(0)$ and $\mathrm{I}(1)$. This validates the use of the ARDL method developed by (Pesaran et al., 2001).

Table 4 shows the result of bound test for co-integration for the selected ARDL $(1,1,0,1,1$, $1,0,1,0)$ model. Based Akaike info criterion (AIC) lag selection method, all variables were specified at lag 1 except, DEA and inflation which were specified at lag 0 . The result

\begin{tabular}{lcccc}
\hline & \multicolumn{2}{c}{ At level } & \multicolumn{2}{c}{ At first difference } \\
Variables & Constant only & Constant and trend & Constant only & Contestant and trend \\
\hline LNGDPC & 1.657761 & -0.679659 & $-4.092726^{* * *}$ & $-5.285872^{* * * *}$ \\
POLITY2 & -1.49948 & -1.61187 & $-5.57919^{* * *}$ & $-5.46866^{* * *}$ \\
MPV & -2.16265 & -2.45727 & $-5.73016^{* * *}$ & $-5.6891^{* * *}$ \\
DEA & -1.42784 & -0.47369 & $-4.75927^{* * *}$ & $-5.06682^{* * *}$ \\
FDI & -0.77555 & -4.92462 & $-4.47756^{* * *}$ & $-4.02121^{* * *}$ \\
LNTOPEN & 0.308094 & -1.78253 & $-4.42987^{* * *}$ & $-4.54109^{* * *}$ \\
POPG & -0.97791 & -2.84799 & $-4.5339^{* * *}$ & $-4.46952^{* * *}$ \\
INF & $-4.56125^{* * *}$ & $-4.8952^{* * *}$ & $-9.21167^{* * *}$ & $-9.07497^{* * *}$ \\
DBY & -2.43019 & -2.43865 & -5.2647 & -5.15411
\end{tabular}

Note(s): the numbers reported are $t$-ratio and the asterisks $* * * *$ and $* *$ indicates the rejection of the null hypothesis of non-stationary at $1 \%, 5 \%$ and $10 \%$ significant level respectively

Source(s): Author's computation using Eviews 11

\begin{tabular}{lccccr}
\hline & & \multicolumn{3}{c}{ Significance level } \\
Bounds test statistic & Value & Bound & $10 \%$ & $5 \%$ & $1 \%$ \\
\hline$F$-statistic & 13.52816 & $\mathrm{I}(0)$ & 1.88 & 2.14 & 2.65 \\
$K$ & 9 & $\mathrm{I}(1)$ & 2.99 & 3.3 & 3.97 \\
$t$-statistic & -6.49752 & $\mathrm{I}(0)$ & -2.57 & -2.86 & -3.43 \\
Selected Model & $\mathrm{I}(1)$ & -4.56 & -4.88 & -5.54 \\
lag selection method & & \multicolumn{3}{c}{ ARDL $(1,1,0,1,1,1,0,1,0)$} \\
Source(s): Author's estimation & & \multicolumn{3}{c}{ (Anfo criterion (AIC) } \\
\end{tabular}

Table 4.

Bounds test for co-integration analysis

\footnotetext{
Source(s): Author's estimation using Eviews 11
} 
confirmed that the value of the $F$-statistic for the joint significance is greater than the upper bound critical values at $1 \%, 5 \%$ and $10 \%$ levels of significance. It is clear from the result that $F$-statistic $=13.52816$, which implies the rejection of the null hypothesis in favor of the alternative hypothesis. Therefore, there is a long-run relationship between the variable in the equation. The $t$-bound test also confirms that there is a long-run relationship among the variable, the absolute value of $t$-test $=6.49752$ is greater than $\mathrm{I}(1)$ at $1 \%, 5 \%$ and $10 \%$ levels.

Table 5 shows the diagnostics test results for the robustness of the ARDL model. The Breusch-Godfrey Serial Correlation LM test and Breusch-Pagan-Godfrey Heteroskedasticity test confirm that residuals are free from serial correlation $(\phi=0.555)$ and heteroskedasticity problems $(\phi=0676)$. Likewise, the value of Jarque-Bera normality test $(p=0.7207)$ is not significant, implying that errors in the series have a normal distribution.

The Ramsey functional form test also confirms that the model is specified well, $p=0.5326$ cannot reject the null hypothesis of the model is correctly specified. Additionally, Figures 1 and 2 depict the result of model stability of the estimated ARDL regression coefficients. As portrayed in the graphs, CUSUM test and square test statistics are neatly within the boundaries at the $5 \%$ significant level. Hence, this confirms the stability of the long-run and short coefficients in the estimated model.

Table 6 shows the estimated long-run effect of political institutions and other convectional macroeconomic variables on economic performance (LNGDPC). The result indicated that the level of democracy (POLITY2) has a negative significant long-run effect on LNGDPC at a 1\% level. This finding confirms the previous finding (Aisen and José, 2013; Das and Quirk, 2016; Iqbal and Daly, 2014). Bardhan (2005) stated that institutions that harm economic performance often tend to persist for long periods in many poor countries. On the other hand, the result shows that political violence (MPV) has no significant long-run effect on the LNGDPC of Ethiopia.

\begin{tabular}{llcc}
\hline Description of test types & Test statistics & Value & Prob \\
\hline Breusch-Godfrey Serial Correlation LM Test & F- Statistics & 0.359225 & 0.5553 \\
Heteroskedasticity Test Breusch-Pagan-Godfrey & F-Statistics & 0.796005 & 0.6760 \\
Specification test: Ramsey RESET Test* & F-Statistics & 0.634568 & 0.5326 \\
Normality Test: Jarque-Bera & & 0.65508 & 0.7207
\end{tabular}

Source(s): Author's calculation using Eviews 11

Table 5. Diagnostics tests of ARDL

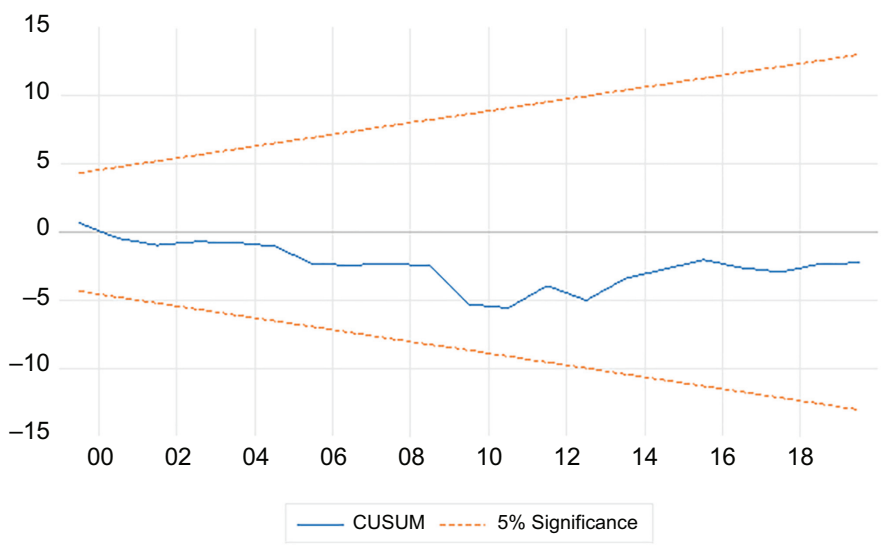

Figure 1 . Cumulative sum (CUSUM) test 
Figure 2.

Cumulative sum (CUSUM) square test

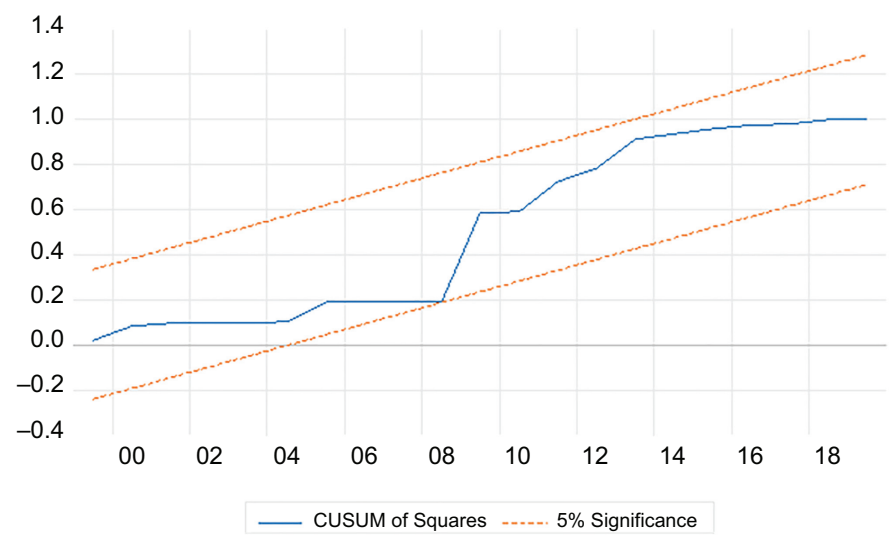

\begin{tabular}{|c|c|c|c|c|}
\hline Regressors & Coefficient & Std. Error & $t$-Statistic & Prob \\
\hline \multicolumn{5}{|c|}{ Dependent variable: $D(L N G D P C)$} \\
\hline POLITY2 & -0.01843 & 0.00587 & -3.13808 & $0.0048^{* * * *}$ \\
\hline MPV & -0.00138 & 0.00553 & -0.25016 & 0.8048 \\
\hline DEA & -0.07520 & 0.01553 & -4.84112 & $0.0001 * * *$ \\
\hline FDI & 0.01073 & 0.00119 & 9.02562 & $0.0000^{* * * *}$ \\
\hline LNTOPEN & 0.32482 & 0.02140 & 15.17793 & 0.0000 *** \\
\hline POPG & 0.06204 & 0.05447 & 1.13886 & 0.2670 \\
\hline INF & -0.00183 & 0.00091 & -2.01269 & $0.0565^{*}$ \\
\hline $\mathrm{DM}_{1991}$ & -0.47854 & 0.13246 & -3.61270 & $0.0015^{* * * *}$ \\
\hline DBY & -0.01000 & 0.00237 & -4.22338 & $0.0003^{* * * *}$ \\
\hline$R$-squared & 0.996775 & \multicolumn{2}{|c|}{ Akaike info criterion } & -4.06363 \\
\hline Adjusted $R$-squared & 0.994429 & \multicolumn{2}{|c|}{ Schwarz criterion } & -3.33849 \\
\hline$F$-statistic & 424.9345 & \multicolumn{2}{|c|}{ Hannan-Quinn criterion } & -3.80345 \\
\hline Prob ( $F$-statistic) & 0.0000 & \multicolumn{2}{|c|}{ Durbin-Watson stat } & 2.200985 \\
\hline \multicolumn{5}{|c|}{ Source(s): Author's estimation using Eviews 11} \\
\hline
\end{tabular}

Also, Table 6 shows that DEA has a negative influence on GDP per capita at the $\%$ level. The result implies that in the long-run DEA adversely influenced economic performance in Ethiopia. It might be because, in a nation where the quality of an institution is dysfunctional, weak democratic institutions, politicians and public officials have fewer checks on their power, making it easier for them to engage in rent-seeking (Iqbal and Daly, 2014; Masaki and Walle, 2014). Likewise, the dummy variable (DU 1991) has an inverse relation with economic performance in the long run. According to CSP (2020), Ethiopia faced complete state failure in 1991. The finding of this study revealed that, in the long run, the impact of DU1991 declined as real GDP per capita increased over time. Moreover, regime durability (DBY) harms real GDPP per capita at a 1\% level. The result implies that keeping all other factors constant, an increase in regime durability by a year led to a decrease in economic performance by $1 \%$ in the long run.

Similarly, the result indicates that most of the standard macroeconomic variables included in this study have a significant effect on economic performance (LNGDPC). In the long run, the inflow of FDI per capita and trade openness (LNTOPEN) has a positive influence on real GDP per capita at a $1 \%$ level. It implies that an increase in FDI by $\$ 1$ per capita led to an improvement in real GDP by $1 \%$, ceteris paribus. Similarly, keeping all other variables 
constant, an increase in trade openness with other nations led to an improvement in real GDP by $32.48 \%$ in Ethiopia. On the other hand, inflation (INF) has a negative significant long-run effect on real GDP per capita at $10 \%$.

Table 7 shows the estimated result of the error correction model, which is the short-run dynamics. The finding indicates that the level of democracy (Polity2) cannot explain economic performance in the short run. However, political violence has short-run inverse relationships with real GDP per capita at a $\%$ level. This finding is consistent with Aisen and José (2013), which found that a higher degree of political instability is associated with lower growth rates of GDP per capita. Bodea and Elbadawi (2008) maintained that organized political violence, especially civil war, significantly lowers long-term economic growth in SubSaharan African.

The result shows that the standard macroeconomic variables inflows of FDI per capita, trade openness (LNTOPEN), and annual population growth (POPG) have a short-run positive effect on economic performance in Ethiopia at $10 \%, 5 \%$, and $1 \%$ level, respectively. The result implies that an increase in FDI, Trade openness and annual population growth led to $0.195 \%, 8.25 \%$, and $36.12 \%$, respectively, ceteris paribus. Moreover, the dummy variable DM1991 has a short-run negative impact on economic performance in Ethiopia, which implies that a decrease in DM1991 would lead to an increase in real GDP per capita. Furthermore, the result indicates that the parameter CointEq. $(-1)$, at the $1 \%$ level, the error correction coefficient is negative and statistically important. This suggests that all the variables have a long-run relationship or are co-integrated. The result suggests that the mechanism corrects its previous time imbalance at a rate of $71.16 \%$ annually.

Table 8 demonstrates the Granger causality test at lags 1 and 2 between variables of political institutions and actual GDP per capita. The result revealed that causality exists between the degree of democracy (measured by POLITY2) and the actual per capita GDP at $10 \%$ and $1 \%$ respectively. The result suggests that economic growth is caused by the level of democracy, but the reverse is not accurate. In addition, political violence (MPV) and real GDP per capita have a strong unidirectional causality at a 1\% level, under lag length 1 , and $5 \%$ level, under lag length 1 . The result suggests that economic growth is caused by political aggression, but the reverse may not be true. This result is consistent with Bruinshoofd (2016) which argues that over the longer term, institutional quality and economic growth improve each other but this virtuous cycle is driven by institutional quality. Similarly, the result shows

\begin{tabular}{|c|c|c|c|c|}
\hline Regressors & Coefficient & Std. error & $t$-Statistic & Prob \\
\hline \multicolumn{5}{|c|}{ Dependent variable: DLNGDPC } \\
\hline $\mathrm{C}$ & 2.48305 & 0.17895 & 13.87600 & $0.0000^{* * * *}$ \\
\hline D (POLITY2) & -0.00243 & 0.00355 & -0.68401 & 0.5011 \\
\hline $\mathrm{D}(\mathrm{MPV})$ & -0.00909 & 0.00284 & -3.19656 & $0.0042^{* * * *}$ \\
\hline $\mathrm{D}(\mathrm{FDI})$ & 0.00195 & 0.00101 & 1.92440 & $0.0673^{*}$ \\
\hline D (LNTOPEN) & 0.08250 & 0.03371 & 2.44766 & $0.0228^{* *}$ \\
\hline $\mathrm{D}(\mathrm{POPG})$ & 0.36126 & 0.04488 & 8.05001 & $0.0000 * * *$ \\
\hline $\mathrm{D}\left(\mathrm{DM}_{1991}\right)$ & -0.10079 & 0.03157 & -3.19285 & $0.0042^{* * * *}$ \\
\hline CointEq $(-1)$ & -0.71608 & 0.05187 & -13.80667 & $0.0000^{* *}$ \\
\hline$R$-squared & 0.91306 & \multicolumn{2}{|c|}{ Akaike info criterion } & -4.5252 \\
\hline Adjusted $R$-squared & 0.89343 & \multicolumn{2}{|c|}{ Schwarz criterion } & -4.1839 \\
\hline$F$-statistic & 46.51080 & \multicolumn{2}{|c|}{ Hannan-Quinn criterion } & -4.4027 \\
\hline Prob. ( $F$-statistic $)$ & 0.0000 & \multicolumn{2}{|c|}{ Durbin-Watson stat } & 2.2010 \\
\hline
\end{tabular}

Note(s): The asterisks $* * *, * *$ and $*$ sign indicates the significance of the coefficients at $1 \%, 5 \%$ and $10 \%$ significant level respectively

Source(s): Author's estimation using Eviews 11

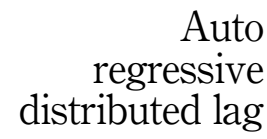

Table 7 .

Estimated coefficients of short run ARDL Error Correction Regression 


\begin{tabular}{lclcl}
\hline & \multicolumn{2}{c}{ Lag: 1} & \multicolumn{2}{c}{ Lag: 2} \\
Null hypothesis & $F$-statistic & Prob & $F$-statistic & \multicolumn{1}{c}{ Prob } \\
\hline POLITY2 does not Granger Cause LNGPDC5 & 3.72722 & $0.0614^{*}$ & 12.508 & $0.00009^{* * * *}$ \\
LNGPDC5 does not Granger Cause POLITY2 & 0.04486 & 0.8335 & 0.35746 & 0.7021 \\
MPV does not Granger Cause LNGPDC5 & 11.2268 & $0.0019^{* * *}$ & 3.95313 & $0.0289^{* *}$ \\
LNGPDC5 does not Granger Cause MPV & 0.13986 & 0.7106 & 0.11238 & 0.894 \\
DEA does not Granger Cause LNGPDC5 & 8.98516 & $0.0049^{* * *}$ & 3.40766 & $0.0451^{* *}$ \\
LNGPDC5 does not Granger Cause DEA & 5.491 & $0.0248^{* *}$ & 3.68685 & $0.0359^{* *}$
\end{tabular}

Table 8.

Pairwise Granger causality tests
Source(s): Author's estimation using Eviews 11

Note(s): The asterisks $* * * * *$ and $*$ sign indicates the significance of the $F$-test at $1 \%, 5 \%$ and $10 \%$ significant level respectively

that there is bidirectional causality between DEA and per capita real GDP, suggesting that economic performance are caused by DEA and vice versa.

\section{Conclusions and recommendations}

\subsection{Conclusion}

Following the studies that have investigated the impact of institutions on economic performance in developing economies, particularly Africa's economies, this study examined how political institutions affect economic performance in Ethiopia over the periods of 1980-2019. The short-run and long-run relationships between political institutions, along with other standard economic variables, are explored by using the Autoregressive Distributed Lag approach to co-integration. Specifically, the effect of Political institutions including the level of democracy, political violence, regime durability, and DEA was investigated.

This finding of this study reveals that the level of democracy and DEA has a long-run adverse impact on Ethiopia's economic performance. The result of the granger causality test confirms that there is a significant long-run causality between these measures of political institution and real GDP per capita. Importantly, this confirms with Kurzman et al. (2002) which affirm that democracy is an obstacle for promoting investment because Democracies regimes dare not impose unpopular measures to increase investment but only an authoritarian regime will be able to do so. Also, political violence has a short-run negative effect on economic performance in Ethiopia. The result of the Granger causality test also confirms that there is a short-run causal relationship between political violence and real GDP per capita. This study concludes that the deterioration of political institutions in Ethiopia hinders its economic performance over the last four decades. The weak quality of institutions prevents it from gaining the benefits of a high continued economic performance, which is depending upon the quality of institutions.

\subsection{Recommendation}

From a policy perspective, the level of democracy and DEA should have to be paid more attention. The government policymakers need to give priories to improving the quality of political institutions. Additionally, better management of political violence has important implications for fostering the economic performance of Ethiopia. This study contributes to the existing literature by examining how the level of democracy, DEA and political violence has influenced economic performance in Ethiopia. However, several political institutions' indicators that economic performance remains unconsidered. Hence, a future study needs to focus on such areas. 


\section{References}

Abeyasinghe, R. (2004), "Democracy, Political Stability, and Developing Country Growth : Theory and Evidence", available at: http://digitalcommons.iwu.edu/econ_honproj/17.

Acemoglu, D. and Robinson, J. (2008), "The role of institutions in growth and development", working paper No. 10, Commission on Growth and Development, Washington, DC, available at: www.worldbank.org.

Acemoglu, D. and Robinson, J.A. (2010a), “The role of institutions in growth and development”, Review of Economics and Institutions, Vol. 1 No. 2, doi: 10.5202/rei.v1i2.1.

Acemoglu, D. and Robinson, J.A. (2010b), “Why Africa is Poor?", Economic History of Developing Regions, Vol. 25 No. 1, pp. 21-50, doi: 10.1080/20780389.2010.505010.

Acemoglu, D., Johnson, S. and Robinson, J.A. (2005), "Institutions as a fundamental cause of long-run growth", in Aghion, P. and Durlauf, S.N. (Eds), Handbook of Economic Gmwth, Vol. 1A, doi: 10 1016/S1574-06849(05)01006-3.

Aisen, A. and José, F. (2013), "How does political instability affect economic growth ?", European Journal of Political Economy, Vol. 29, pp. 151-167, doi: 10.1016/j.ejpoleco.2012.11.001.

Araee, M. (2016), Economic Growth, Democracy and Political Instability: Cross Country Analysis, Doctor of Philosophy Thesis, School of Accounting, Economics and Finance, University of Wollongong, available at: https://ro.uow.edu.au/theses/4767\%0AResearch.

Araya, E.K. (2019), Political Control and Accountability in Ethiopian Rulemaking, Walden University, available at: https://scholarworks.waldenu.edu/dissertations.

Aron, J. (2000), "Growth and Institutions: a review of the evidence", The Wolrd Bank Research Observer, Vol. 15 No. 1, pp. 99-135, available at: http://about.jstor.org/terms.

Asefa, S. (2018), "Developing democratic institutions in Ethiopia : the challenge of building enabling institutions for economic growth and development”, Northeast African Studies, Vol. 10 No. 1, pp. 67-113, doi: 10.1353/nas.0.0011.

Asfaw, K. and Mbeche, I.M. (2006), "The role of institutions in the development process of African countries", International Journal of Social Economics, Vol. 31 No. 9, pp. 840-854, doi: 10.1108/ 03068290410550638

Bardhan, P. (2005), "Institutions matter, but which ones ?", Economics of Transition, Vol. 13 No. 3, pp. 499-532.

Bayu, T.B. (2019), "Measuring governance performance - post 1991 Ethiopia", Smart Cities and Regional Development Journal, Vol. 12, pp. 33-47.

Bodea, C. and Elbadawi, I.A. (2008), "Political violence and economic growth", Policy Research Working Paper 4692, Washington, DC, doi: 10.1093/jae/ejn018.

Bruinshoofd, A. (2016), Institutional Quality and Economic Performance, Rabobank/RaboResearch, Utrecht, pp. 1-22.

Das, K. and Quirk, T. (2016), "Which institutions promote Growth? Revisiting the evidence", Economic Papers, Vol. 35 No. 1, pp. 37-58, doi: 10.1111/1759-3441.12128.

Effiong, E. (2015), The Role of Institutions and Governance on Economic Performance in Selected Subsaharan African Countries, University of Nigeria.

Fikadu, A., Wondaferahu, M. and Tesfaye, M. (2019), "Impact of institutional quality on economic performance of Eastern Africa: a panel data analysis", Jurnal Perspektif Pembiayaan Dan Pembangunan Daerah, Vol. 7 No. 2, pp. 169-182, doi: 10.22437/ppd.v7i2.7863.

Heshmati, A. and Kim, N. (2017), "The relationship between economic growth and democracy: Alternative representations of technological change", IZA DP No.10880, available at: www.iza.org.

IPSS (2020), Ethiopia Conflict Insight, Vol. 1, Addis Ababa University, available at: www.ipss-addis. org/publications.

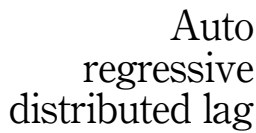

$-$ 
JED

24,1

Iqbal, N. and Daly, V. (2014), "Rent seeking opportunities and economic growth in transitional economies”, Economic Modelling, Vol. 37, pp. 16-22, doi: 10.1016/j.econmod.2013.10.025.

Knutsen, C.H. (2012), "Democracy and economic growth: a survey of arguments and results", International Area Studies Review, Vol. 15 No. 4, pp. 393-415, doi: 10.1177/2233865912455268.

Kurzman, C., Werum, R. and Burkhart, R.E. (2002), "Democracy's effect on economic growth: a pooled time-series analysis, 1951-1980", Studies in Comparative International Development, Vol. 37 No. 1, pp. 3-33.

Leeuwen, B. (2008), "Problems in analyzing economic development", in Human Capital and Economic Growth Problems, pp. 1-18.

Mankiw, N.G., Romer, D. and Weil, D.N. (1992), "A contribution to the empirics of economic growth", Quarterly Journal of Economics, Vol. 10 No. 2, pp. 407-437.

Marshall, M.G. (2019), “Major Episodes of Political Violence (MEPV) and Conflict Regions, 1946-2018”, available at: www.systemicpeace.org.

Marshall, M.G. and Gurr, T.R. (2020), "POLITY5: Political Regime Characteristics and Transitions, 1800-2018”, available at: www.systemicpeace.org.

Masaki, T. and Walle, N. (2014), "The impact of democracy on economic growth in Sub-saharan Africa, 1982-2012", WIDER Working Paper 2014/057, available at: wider.unu.edu.

Matthew, A.O. and Adegboye, B.F. (2014), "Trade openness, institutions and economic growth in subSaharan Africa”, Developing Country Studies, Vol. 4 No. 8, pp. 18-31, available at: www.iiste.org.

Nawaz, S. (2015), "Growth effects of institutions: a disaggregated analysis", Economic Modelling, Vol. 45, pp. 118-126, doi: 10.1016/j.econmod.2014.11.017.

North, D.C. (1990a), Institutions, Institutional Change and Economic Performance, Cambridge University Press, Cambridge.

North, D.C. (1990b), Institutions, Institutional Change and Economic Performance, Cambridge University Press.

North, D.C. and Thomas, R.P. (1973), The Rise of the Western World: A New Economic History, Cambridge University Press, Cambridge.

Pereira, C. and Teles, V.K. (2009), "Institutions as substitute for democracy: A political economy analysis of economic growth", Texto para discussao 196, FGV EESP - Escola de Economia de São Paulo, Fundação Getulio Vargas (Brazil).

Pesaran, M.H., Shin, Y. and Smith, R.J. (2001), "Bounds testing approaches to the analysis of level relationships", Journal of Applied Econometrics, Vol. 16 No. 3, pp. 289-326, doi: 10.1002/jae.616.

Popescu, I. (2012), "Institutions and economic growth theory", in Advances in Economics, Risk Management, Political and Law Science Institutions, University of Isaii, pp. 253-256.

Rachdi, H. and Saidi, H. (2015), "Democracy and economic growth: evidence in MENA countries", Procedia - Social and Behavioral Sciences, Vol. 191, pp. 616-621, doi: 10.1016/j.sbspro.2015. 04.644 .

Sardadvar, S. (2011), Neoclassical Growth Theory and Standard Models, Springer-Verlag Berlin Heidelberg, Vol. 1, doi: 10.1007/978-3-7908-2637-1.

Shrestha, M.B. and Bhatta, G.R. (2018), "Selecting appropriate methodological framework for time series data analysis", The Journal of Finance and Data Science, Vol. 4 No. 2, pp. 71-89, doi: 10. 1016/j.jfds.2017.11.001.

Tavares, H. and Wacziarg, R. (2001), "How democracy a! ects growth", European Economic Review, Vol. 45, pp. 1341-1378, doi: 10.1016/S0014-2921(00)00093-3.

Temin, P. (2008), Institutions and Economic Performance, MIT Press.

Vitola, A. and Senfelde, M. (2015a), "The role of institutions in economic performance", Teorija IR Praktika / Business, Vol. 16 No. 3, pp. 271-279, doi: 10.3846/btp.2015.498. 
Vitola, A. and Senfelde, M. (2015b), "The role of institutions in economic performance", Teorija IR Praktika / Business, Vol. 16 No. 3, pp. 271-279, doi: 10.3846/btp.2015.498.

Vitola, A. and Senfelde, M. (2012), "Institutions and economic performance", Economics and Business, pp. 181-188, available at: https://ortus.rtu.lv/science/en/publications/14063.

WB (2016), ETHIOPIA'S GREAT RUN: The Growth Acceleration and How to Pace it, Washington, DC.

\section{Further reading}

Flachaire, E., García-peñalosa, C. and Konte, M. (2014), "Political versus economic institutions in the growth process", Journal of Comparative Economics, Vol. 42 No. 1, pp. 212-229, doi: 10.1016/j.jce. 2013.05.001.

Harrison, A. (1996), "Openness and growth: a time-series , cross-country analysis for developing countries", Journal of Development Economics, Vol. 48, pp. 419-447.

Lehne, J., Mo, J. and Plekhanov, A. (2014), "What determines the quality of economic institutions? Cross-country evidence”, EBRD Working Paper No. 171, European Bank for Reconstruction and Development.

Nosier, S. and El-karamani, A. (2018), "The indirect effect of democracy on economic growth in the MENA region (1990-2015)”, Economies, Vol. 6 No. 61, pp. 1-24, doi: 10.3390/economies6040061.

UNODC (2013), Transnational Organized Crime in Eastern Africa: A Threat Assessment, United Nations Office on Drugs and Crime, Vienna.

\section{Corresponding author}

Fikadu Abera Garedow can be contacted at: fikabra@gmail.com

For instructions on how to order reprints of this article, please visit our website:

www.emeraldgrouppublishing.com/licensing/reprints.htm

Or contact us for further details: permissions@emeraldinsight.com 